\title{
Regulation of Bone Health Parameters in MG-63 Cell Line After Treatment with Biofield Energy Treated Vitamin $D_{3}$
}

\author{
Matthew Charles Hornung ${ }^{1}$, Mahendra Kumar Trivedi ${ }^{1}$, Alice Branton ${ }^{1}$, Dahryn Trivedi ${ }^{1}$, \\ Gopal Nayak ${ }^{1}$, Mayank Gangwar ${ }^{2}$, Snehasis Jana ${ }^{2,}$, \\ ${ }^{1}$ Trivedi Global, Inc., Henderson, USA \\ ${ }^{2}$ Trivedi Science Research Laboratory Pvt. Ltd., Bhopal, India
}

Email address:

publication@trivedisrl.com (S. Jana)

*Corresponding author

\section{To cite this article:}

Matthew Charles Hornung, Mahendra Kumar Trivedi, Alice Branton, Dahryn Trivedi, Gopal Nayak, Mayank Gangwar, Snehasis Jana. Regulation of Bone Health Parameters in MG-63 Cell Line After Treatment with Biofield Energy Treated Vitamin $\mathrm{D}_{3}$. American Journal of Biomedical and Life Sciences. Vol. 6, No. 1, 2018, pp. 9-16. doi: 10.11648/j.ajbls.20180601.12

Received: January 21, 2018; Accepted: February 1, 2018; Published: March 2, 2018

\begin{abstract}
The present experiment aimed to explore the potential of Consciousness Energy Healing based vitamin $\mathrm{D}_{3}$ and DMEM medium on various bone health parameters such as alkaline phosphatase enzyme (ALP) activity, collagen levels and bone mineralization. The test items (TI) i.e. vitamin $\mathrm{D}_{3}$ and DMEM medium were divided into two parts. The test items received the Consciousness Energy Healing Treatment by Matthew Charles Hornung and those samples were labeled as the Biofield Energy Treated (BT) samples, while the other parts of both the sample were denoted as the untreated test items (UT). Cell viability using MTT assay showed that cell viability in tested samples was more than $88 \%$ on MG-63 cell line. ALP level was significantly increased by $273.3 \%$ (at $0.1 \mu \mathrm{g} / \mathrm{mL}$ ), $694.1 \%$ (at $1 \mu \mathrm{g} / \mathrm{mL}$ ), and $180 \%$ (at $0.1 \mu \mathrm{g} / \mathrm{mL}$ ) in UT-DMEM+BT-TI, BT-DMEM+UT-TI, and BT-DMEM+BT-TI groups, respectively as compared with the untreated test item and DMEM group. Collagen level was significantly increased by $105.8 \%$ (at $1 \mu \mathrm{g} / \mathrm{mL}$ ), $164.6 \%$ (at $0.1 \mu \mathrm{g} / \mathrm{mL}$ ), and $193.8 \%($ at $0.1 \mu \mathrm{g} / \mathrm{mL}$ ) in UTDMEM+BT-TI, BT-DMEM+UT-TI, and BT-DMEM+BT-TI groups, respectively as compared with the untreated test item and DMEM group. Bone mineralization percentage was significantly increased by $238.1 \%, 92.7 \%$, and $43.1 \%$ at $0.1,1$, and 10 $\mu \mathrm{g} / \mathrm{mL}$, respectively in UT-DMEM+BT-TI group, while $297.6 \%, 86.2 \%$, and $66.3 \%$ at $0.1,1$, and $10 \mu \mathrm{g} / \mathrm{mL}$, respectively in BT-DMEM+UT-TI group as compared with the untreated group. In addition, BT-DMEM+BT-TI group showed a significant increased bone mineralization by $281 \%, 113 \%$, and $47 \%$ at $0.1,1$, and $10 \mu \mathrm{g} / \mathrm{mL}$, respectively as compared with the untreated group. Overall, the experimental data suggested that the Biofield Energy Treated vitamin $\mathrm{D}_{3}$ and DMEM would play an important role in the promotion and maintenance of strong and healthy bones, which improve quality of life. Biofield Energy Treatment might also regulates the osteoblast function, improves bone mineralization, and calcium absorption in wide range of bone disorders along with wide range of adverse health conditions, comprising cancer and certain autoimmune diseases.
\end{abstract}

Keywords: Biofield Energy, Osteosarcoma Cells, Vitamin D, Osteoporosis, Bone Disorders, Bone Mineralization

\section{Introduction}

Vitamin D has multiple effects which regulate the functions in different organs such as brain, lungs, liver, kidneys, and heart, immune, skeletal, and reproductive systems. Moreover, it has significant anti-inflammatory, anti-arthritic, anti-osteoporosis, anti-stress, anti-aging, anti-apoptotic, wound healing, anti-cancer, anti-psychotic, and anti-fibrotic roles. Vitamin D receptors (VDRs) are widely present in most of the body organs like brain, heart, lungs, kidney, liver, pancreas, large and small intestines, muscles, reproductive, nervous system, etc. [1]. VDRs influence cell-to-cell communication, normal cell growth, cell differentiation, cell cycling and proliferation, hormonal balance, neurotransmission, skin health, immune and cardiovascular functions. Bone-related health issues become a major problem among the population from village to the cities. Vitamin D plays a vital role in preserving a healthy mineralized skeleton of most of the vertebrates including humans. Cod liver oil, irradiation of 
other foods including plants, sunlight, etc. are found to be effective against bone related disorders, which lead to discovering the active principle- vitamin $\mathrm{D}$ [1]. The role of vitamin $\mathrm{D}$ has been well defined not only for improving the bone mineralization but also with increased bone resorption, aging, inflammation and overall quality of life. Vitamin $\mathrm{D}_{3}$ is synthesized in the skin by sunlight and once formed it sequentially metabolized in the liver and kidney to 1,25dihydroxyvitamin D (calcitriol, the vitamin D hormone) [2]. Calcitriol play an important role in maintaining the normal level of calcium and phosphorus, promotes bone mineralization, induce or repress the genes responsible for conserving the mineral homeostasis and skeletal integrity, and inhibit hypertension, kidney damage, cardiovascular and immune disorders (such as Lupus, Addison Disease, Graves' Disease, Hashimoto Thyroiditis, Multiple Sclerosis, Myasthenia Gravis, Anemia, Sjogren Syndrome, Systemic Lupus Erythematosus, Diabetes, Alopecia Areata, Fibromyalgia, Vitiligo, Psoriasis, Scleroderma, Chronic Fatigue Syndrome and Vasculitis), and the secondary hyperparathyroidism [3]. Vitamin D insufficiency and deficiency is the major health problem, which causes metabolic bone disease in the young and elderly populations [4]. Fortified foods have a variable amount of vitamin D and most of the foods do not contain vitamin D, which can be fulfilled using some supplements. In order to avoid the bone related disorders such as osteomalacia, exacerbate osteoporosis, hyperparathyroidism, immune disorders, etc. calcium 1000-1500 $\mathrm{mg}$ /day along with vitamin D supplement around $400 \mathrm{IU} /$ day is very important for maintaining the good bone health [5].

Various in vitro studies have readily demonstrated the role of bone health using cell lines and its resorbing effects using three important key biomarkers, such as alkaline phosphatase (ALP), collagen and calcium. MG-63 cell line derived from juxtacortical osteosarcoma, which represents an immature osteoblast phenotype and undergoes temporal development in long term culture. The response of MG-63 cells to 1,25dihydroxyvitamin $\mathrm{D}_{3}\left(1,25(\mathrm{OH}) 2 \mathrm{D}_{3}\right)$ administration has been studied to be similar to normal human osteoblast cells [6]. Hence, MG-63 cell line is widely used for studying the potential of any test compounds to improve the bone health [7]. The formation of new bone involves a complex series of events including the proliferation and differentiation of osteoblasts, and eventually the formation of a mineralized extracellular matrix. ALP is a phenotypic marker for the early differentiation and maturation of osteoblasts. ALP increases the local concentration of inorganic phosphate for bone mineralization and hence is an important marker for osteogenic activity [8]. Similarly, active osteoblasts synthesize and extrude collagen, which plays an important role in the formation of bone extracellular matrix by providing strength and flexibility. Collagen fibrils formed an arrays of an organic matrix known as Osteoid [9]. Likewise, calcium phosphate is deposited in the Osteoid and gets mineralized (combination of calcium phosphate and hydroxyapatite) and provides rigidity to the bone [10]. Thus, these parameters are very essential in order to study the bone health in cell lines. Authors evaluated the in vitro effect of the Biofield Energy Treated vitamin $\mathrm{D}_{3}$ as a test item, a Complementary and Alternative Medicine (CAM) on bone health using MG-63 cell line for major biomarkers.

Within the burgeoning ground of CAM therapies, Biofield Energy Treatment or energy medicine, is emerging with significant benefits in various scientific fields. The effects of the CAM therapies have great potential, which include external qigong, Johrei, Reiki, therapeutic touch, yoga, Qi Gong, polarity therapy, Tai Chi, pranic healing, deep breathing, chiropractic/osteopathic manipulation, guided imagery, meditation, massage, homeopathy, hypnotherapy, progressive relaxation, acupressure, acupuncture, special diets, relaxation techniques, Rolfing structural integration, healing touch, movement therapy, pilates, mindfulness, Ayurvedic medicine, traditional Chinese herbs and medicines in biological systems both in vitro and in vivo [11]. Biofield Energy Healing Treatment (The Trivedi Effect ${ }^{\mathbb{B}}$ ) contain a putative bioenergy, which is channeled by a renowned practitioners from a distance. Biofield Energy Healing as a CAM showed a significant results in biological studies [12]. However, the National Center for Complementary and Alternative Medicine (NCCAM), welldefined Biofield therapies in the subcategory of Energy Therapies [13]. The Trivedi Effect ${ }^{\circledR}$ - Consciousness Energy Healing Treatment has been reported with significant revolution in the physicochemical properties of metals, chemicals, ceramics and polymers [14-16], improved agricultural crop yield, productivity, and quality $[17,18]$, transformed antimicrobial characteristics [19-21], biotechnology [22-23], improved bioavailability [24-26], skin health [27, 28], nutraceuticals [29, $30]$, cancer research $[31,32]$, and human health and wellness.

Based on the significant outcomes of Biofield Energy Treatment and vital role of vitamin $\mathrm{D}_{3}$ on bone health, authors sought to evaluate the impact of the Biofield Energy Treatment (The Trivedi Effect ${ }^{\circledR}$ ) on vitamin $\mathrm{D}_{3}$ as test sample for bone health activity with respect to the assessment of different bone health parameters like ALP, collagen content, and bone mineralization using standard in vitro assays in MG-63 cells.

\section{Material and Methods}

\subsection{Chemicals and Reagents}

Rutin hydrate was purchased from TCI, Japan, while vitamin $\mathrm{D}_{3}$ (denoted as test item) and L-ascorbic acid were obtained from Sigma-Aldrich, USA. Fetal bovine serum (FBS) and Dulbecco's Modified Eagle's Medium (DMEM) were purchased from Life Technology, USA. Antibiotics solution (penicillin-streptomycin) was procured from HiMedia, India, while 3-(4, 5-diamethyl-2-thiazolyl)-2, 5diphenyl-2H-tetrazolium) (MTT), Direct Red 80, and ethylene diamine tetra acetic acid (EDTA) were purchased from Sigma, USA. All the other chemicals used in this experiment were analytical grade procured from India.

\subsection{Cell Culture}

Human bone osteosarcoma cell line -MG-63 was used as test system in the present study. The MG-63 cell line was 
maintained in DMEM growth medium for routine culture supplemented with $10 \%$ FBS. Growth conditions were maintained as $37{ }^{\circ} \mathrm{C}, 5 \% \mathrm{CO}_{2}$ and $95 \%$ humidity and subcultured by trypsinisation followed by splitting the cell suspension into fresh flasks and supplementing with fresh cell growth medium. Three days before the start of the experiment (i.e., day -3), the growth medium of nearconfluent cells was replaced with fresh phenol-free DMEM, supplemented with 10\% charcoal dextran stripped FBS (CDFBS) and 1\% penicillin-streptomycin [33].

\subsection{Experimental Design}

The experimental groups consisted of cells in baseline control, vehicle control groups (0.05\% DMSO with Biofield Energy Treated and untreated DMEM), positive control group (rutin hydrate) and experimental test groups. The experimental groups included the combination of the Biofield Energy Treated and untreated vitamin $\mathrm{D}_{3} / \mathrm{DMEM}$. It consisted of four major treatment groups on specified cells with Untreated-DMEM + Untreated-Test item (UT-TI), UTDMEM + Biofield Energy Treated test item (BT-TI), BTDMEM + UT-TI, and BT-DMEM + BT-TI.

\subsection{Consciousness Energy Healing Treatment Strategies}

The test item and DMEM were divided into two parts. One part each of the test item and DMEM was treated with the Biofield Energy by a renowned Biofield Energy Healer (also known as The Trivedi Effect ${ }^{\circledR}$ ) and coded as the Biofield Energy Treated item, while the second part did not receive any sort of treatment. This Biofield Energy Healing Treatment was provided by Matthew Charles Hornung remotely for $\sim 5$ minutes. Biofield Energy Healer was remotely located in the USA, while the test samples were located in the research laboratory of Dabur Research Foundation, New Delhi, India. This Biofield Energy Treatment was administered for 5 minutes through the Healer's unique Energy Transmission process remotely to the test samples under laboratory conditions. Matthew Charles Hornung in this study never visited the laboratory in person, nor had any contact with the test item and medium. Further, the control group was treated with a sham healer for comparative purposes. The sham healer did not have any knowledge about the Biofield Energy Treatment. After that, the Biofield Energy Treated and untreated samples were kept in similar sealed conditions for experimental study.

\subsection{Determination of Non-cytotoxic Concentration}

The cell viability was performed by MTT assay in human bone osteosarcoma cell line (MG-63). The cells were counted and plated in 96 well plates at the density corresponding to $5 \mathrm{X}$ $10^{3}$ to $10 \times 10^{3}$ cells/well/180 $\mu \mathrm{L}$ of cell growth medium. The above cells were incubated overnight under growth conditions and allowed the cell recovery and exponential growth, which were subjected to serum stripping or starvation. The cells were treated with the test item, DMEM, and positive control. The untreated cells were served as baseline control. The cells in the above plate(s) were incubated for a time point ranging from 24 to 72 hours in $\mathrm{CO}_{2}$ incubator at $37^{\circ} \mathrm{C}, 5 \% \mathrm{CO}_{2}$, and $95 \%$ humidity. Following incubation, the plates were taken out and $20 \mu \mathrm{L}$ of $5 \mathrm{mg} / \mathrm{mL}$ of MTT solution were added to all the wells followed by additional incubation for 3 hours at $37^{\circ} \mathrm{C}$. The supernatant was aspirated and $150 \mu \mathrm{L}$ of DMSO was added to each well to dissolve formazan crystals. The absorbance of each well was read at $540 \mathrm{~nm}$ using Synergy HT micro plate reader, BioTek, USA [34]. The percentage cytotoxicity at each tested concentrations of the test substance were calculated using the following equation (1):

$$
\% \text { Cytotoxicity }=(1-\mathrm{X} / \mathrm{R}) * 100
$$

Where, $\mathrm{X}=$ Absorbance of treated cells; $\mathrm{R}=$ Absorbance of untreated cells

The percentage cell viability corresponding to each treatment was obtained using the following equation (2):

$$
\% \text { Cell Viability }=100-\% \text { Cytotoxicity }
$$

The concentrations exhibiting $\geq 70 \%$ Cell viability was considered as non-cytotoxic.

\subsection{Assessment of Alkaline Phosphatase (ALP) Activity}

The cells were counted using an hemocytometer and plated in a 24-well plate at the density corresponding $1 \times 10^{4}$ cells/well in phenol free DMEM supplemented with $10 \%$ CD-FBS. Following respective treatments, the cells in the above plate were incubated for 48 hours in $\mathrm{CO}_{2}$ incubator at $37^{\circ} \mathrm{C}, 5 \% \quad \mathrm{CO}_{2}$, and $95 \%$ humidity. After 48 hours of incubation, the plate was taken out and processed for the measurement of ALP enzyme activity. The cells were washed with $1 \mathrm{X}$ PBS and lysed by freeze thaw method i.e., incubation at $-80^{\circ} \mathrm{C}$ for 20 minutes followed by incubation at $37^{\circ} \mathrm{C}$ for 10 minutes. To the lysed cells, $50 \mu \mathrm{L}$ of substrate solution i.e., $5 \mathrm{mM}$ of $p$-nitrophenyl phosphate ( $p$ NPP) in $1 \mathrm{M}$ diethanolamine and $0.24 \mathrm{mM}$ magnesium chloride $\left(\mathrm{MgCl}_{2}\right)$ solution ( $\mathrm{pH}$ 10.4) was added to all the wells followed by incubation for 1 hour at $37^{\circ} \mathrm{C}$. The absorbance of the above solution was read at $405 \mathrm{~nm}$ using Synergy HT micro plate reader (Biotek, USA). The absorbance values obtained were normalized with substrate blank ( $p$ NPP solution alone) absorbance values [33]. The percentage increase in ALP enzyme activity with respect to the untreated cells (baseline group) was calculated using equation (3):

$$
\% \text { Increase }=[(\mathrm{X}-\mathrm{R}) / \mathrm{R})]^{*} 100
$$

Where, $\mathrm{X}=$ Absorbance of cells corresponding to positive control and test groups

$\mathrm{R}=$ Absorbance of cells corresponding to baseline group (untreated cells)

\subsection{Assessment of Collagen Synthesis}

The MG-63 cells were counted using an hemocytometer and plated in 24-well plate at the density corresponding to $10 \times 10^{3}$ cells/well in phenol free DMEM supplemented with $10 \%$ CD- 
FBS. Following respective treatments, the cells in the above plate were incubated for 48 hours in $\mathrm{CO}_{2}$ incubator at $37^{\circ} \mathrm{C}$, $5 \% \mathrm{CO}_{2}$, and $95 \%$ humidity. After 48 hours of incubation, the plate was taken out and the amount of collagen accumulated in MG-63 cells corresponding to each treatment was measured by Direct Sirius red dye binding assay. In brief, the cell layers were washed with PBS and fixed in Bouin's solution (5\% acetic acid, $9 \%$ formaldehyde and $0.9 \%$ picric acid) for 1 hours at room temperature (RT). After 1 hour of incubation, the above wells were washed with milliQ water and air dried. The cells were then stained with Sirius red dye solution for 1 hour at RT followed by washing in $0.01 \mathrm{~N} \mathrm{HCl}$ to remove unbound dye. The collagen dye complex obtained in the above step was dissolved in $0.1 \mathrm{~N} \mathrm{NaOH}$ and absorbance was read at $540 \mathrm{~nm}$ using Biotek Synergy HT micro plate reader. The level of collagen was extrapolated using standard curve obtained from purified Calf Collagen Bornstein and Traub Type I (Sigma Type III) [33]. The percentage increase in collagen level with respect to the untreated cells (baseline group) was calculated using equation (4):

$$
\% \text { Increase }=[(\mathrm{X}-\mathrm{R}) / \mathrm{R}] * 100
$$

Where, $\mathrm{X}=$ Collagen levels in cells corresponding to positive control and test groups

$\mathrm{R}=$ Collagen levels in cells corresponding to baseline group (untreated cells)

\subsection{Assessment of Bone Mineralization by Alizarin Red S Staining}

The MG-63 cells were counted using an hemocytometer and plated in 24-well plate at the density corresponding to 10 $\mathrm{x} 10^{3}$ cells/well in phenol free DMEM supplemented with $10 \%$ CD-FBS. Following respective treatments, the cells in the above plate were incubated for 48 hours in $\mathrm{CO}_{2}$ incubator at $37^{\circ} \mathrm{C}, 5 \% \mathrm{CO}_{2}$, and $95 \%$ humidity to allow cell recovery and exponential growth. Following overnight incubation, the above cells will be subjected to serum stripping for 24 hours. The cells will be then be treated with non-cytotoxic concentrations of the test samples and positive control. After 3-7 days of incubation with the test samples and positive control, the plates were taken out cell layers and processed further for staining with Alizarin Red $\mathrm{S}$ dye. The cells were fixed in $70 \%$ ethanol for 1 hour, after which Alizarin Red solution ( $40 \mu \mathrm{m} ; \mathrm{pH} 4.2$ ) was added to the samples for 20 minutes with shaking. The cells were washed with distilled water to remove unbound dye. For quantitative analysis by absorbance evaluation, nodules were solubilized with $10 \%$ cetylpyridinium chloride for 15 minutes with shaking. Absorbance was measured at $562 \mathrm{~nm}$ using Biotek Synergy HT micro plate reader [33]. The percentage increase in bone mineralization with respect to the untreated cells (baseline group) was calculated using the following equation (5):

$$
\% \text { Increase }=[(\mathrm{X}-\mathrm{R}) / \mathrm{R}]^{*} 100
$$

Where, $\mathrm{X}=$ Absorbance in cells corresponding to positive control or test groups; $\mathrm{R}=$ Absorbance in cells corresponding to baseline (untreated) group.

\subsection{Statistical Analysis}

All the values were represented as percentage of respective parameters. For multiple group comparison, one-way analysis of variance (ANOVA) was used followed by posthoc analysis by Dunnett's test. Statistically significant values were set at the level of $p \leq 0.05$.

\section{Results and Discussion}

\subsection{Cell Viability Study Using MTT}

MTT assay was used to study the cell viability in the Biofield Energy Treated test samples (vitamin $\mathrm{D}_{3}$ and DMEM medium) in MG-63 cells, and the results in term of percentage are presented in Figure 1. The percentage of cell viability in various tested groups showed a significant improved cell viability. The results showed that both the test items in combination at tested concentration ranges were found to have significant cell viability with more than $88 \%$. The results of cell viability assay showed that the Biofield Energy Treatment showed a significant improved cell viability as compared with the untreated test items. The results suggested that the test items along with DMEM groups were found safe up to maximum of $100 \mu \mathrm{g} / \mathrm{mL}$ against the tested MG-63 cells. Thus, different concentrations i.e. safe concentrations are used to study the bone health parameters such as on the levels of ALP activity, collagen synthesis, and bone mineralization in MG-63 cells.

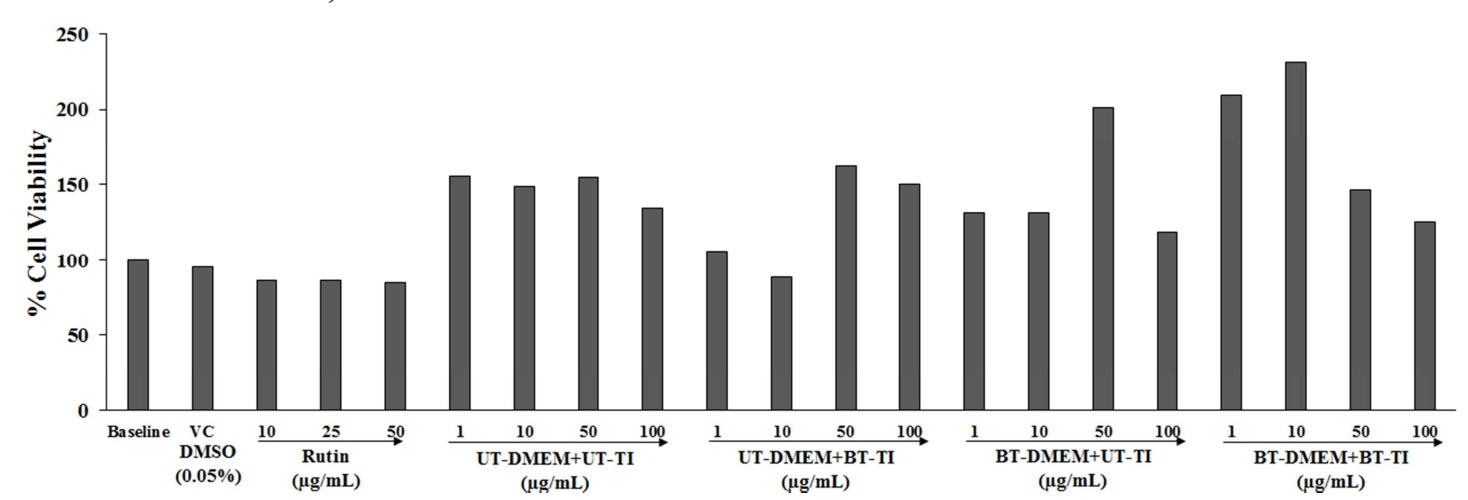

Figure 1. MTT assays of the test formulations on MG-63 cell line after 72 hours. VC: Vehicle control (DMSO-0.05\%), UT: Untreated; BT: Biofield Treated; TI: Test Item. 


\subsection{Study of Alkaline Phosphatase (ALP) Enzyme Activity}

ALP enzyme level was evaluated on MG-63 cell line at various concentrations in Biofield Energy Treated test item and DMEM groups (Figure 2). The results in terms of percentage ALP were described and compared with respect to the untreated group. The positive control, rutin showed a significant increased values of ALP by $39.07 \%, 46.45 \%$, and $80.87 \%$ with respect to the untreated cells. The experimental test group's viz. untreated medium and Biofield Treated Test item (UT-DMEM+BT-TI) showed a significant increase in the ALP level by $273.3 \%$ at $0.1 \mu \mathrm{g} / \mathrm{mL}$, while the Biofield Treated medium and untreated Test item (BT-DMEM+UT-TI) showed a significant increased ALP level by $13.3 \%, 694.1 \%$, and $36.4 \%$ at $0.1,1$, and $10 \mu \mathrm{g} / \mathrm{mL}$, respectively as compared with the untreated test item and DMEM group. However, the Biofield Energy Treated medium and Biofield Energy Treated Test item (BT-DMEM+BT-TI) showed a significant increased ALP level by $180.0 \%$ and $35.3 \%$ at 0.1 and 1 $\mu \mathrm{g} / \mathrm{mL}$, respectively as compared with the untreated test item and DMEM group. ALP for bone is beneficial for the formation of bone cell and growth. Data suggest that altered level of ALP may results in bone related disorders like postmenopausal women, osteoporosis, bone cancers, Paget's disease of bone, healing fracture, bone growth, acromegaly, myelofibrosis, osteogenic sarcoma, or bone metastases, leukemia, and rarely myeloma that can be resolved by addition of medicinal supplementation [35-37]. Experimental study showed that the level of ALP after Biofield Energy Healing Treatment was increased significantly, which can be used as an alternative supplementation with respect to synthetic compounds to treat various bone related diseases like osteoporosis, in middle and old-aged, post- and menopausal women [36]. Overall, the data concluded that The Trivedi Effect ${ }^{\circledR}$-Energy of Consciousness Healing based vit $\mathrm{D}_{3}$ and DMEM could be used to improve the ALP concentration in many bone disorders.

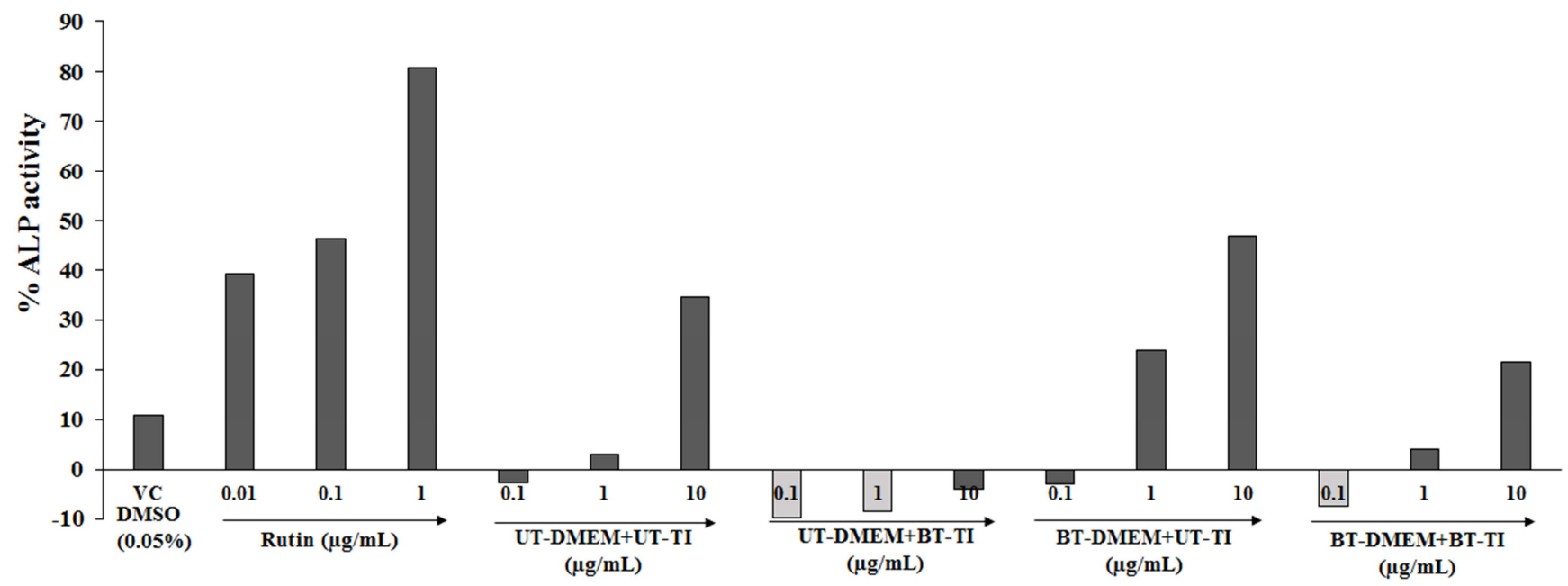

Figure 2. Estimation of ALP enzyme activity of the Biofield Energy Treated test items on MG-63 cell line. VC: Vehicle control (DMSO-0.05\%), UT: Untreated; BT: Biofield Treated; TI: Test Item.

\subsection{Assessment of Collagen Synthesis}

Collagen and its synthesis plays an important role in bone formation and its strength. Improved collagen level would improve the bone mass and minimize the risk of many pathology of bone diseases such as osteoarthritis and osteoporosis. Collagen as a nutritional supplements are now available for bone health against many common bone related disorders. Biofield Energy Treated vit $\mathrm{D}_{3}$ and DMEM were estimated for the level of collagen among various tested concentrations. The results of collagen are presented as $\%$ values with respect to the untreated cells in Figure 3. The rutin hydrate showed a significant increased value of collagen by $29.56 \%, 46.80 \%$, and $51.48 \%$ at $0.01,0.1$, and 1 $\mu \mathrm{g} / \mathrm{mL}$, respectively. Besides, the experimental test groups such as UT-DMEM+BT-TI showed a significant increased collagen level by $105.8 \%$ and $14.5 \%$ at 1 and $10 \mu \mathrm{g} / \mathrm{mL}$, respectively while BT-DMEM+UT-TI group showed a significant increased collagen level by $164.6 \%$ and $74.8 \%$ at 0.1 and $1 \mu \mathrm{g} / \mathrm{mL}$, respectively as compared with the untreated test item and DMEM group. However, BTDMEM+BT-TI group showed a significant increased collagen level by $193.8 \%$ and $58.3 \%$ at 0.1 and $1 \mu \mathrm{g} / \mathrm{mL}$, respectively as compared with the untreated test item and DMEM group. The study data suggest that Biofield Energy Treatment showed a significant improved level of collagen, which might be an alternative source of treatment strategy with high level of safety in chronic bone disorders. Data suggest that collagen level was gradually reduced and its synthesis also hampered with age, so it can be maintained using different nutritional factors [38, 39]. The Trivedi Effect $^{\circledR}$ treatment on vit $\mathrm{D}_{3}$ showed a significant improved collagen level in MG-63 cell line, which can be used against bone diseases, decrease aging process, and its related inflammation. 


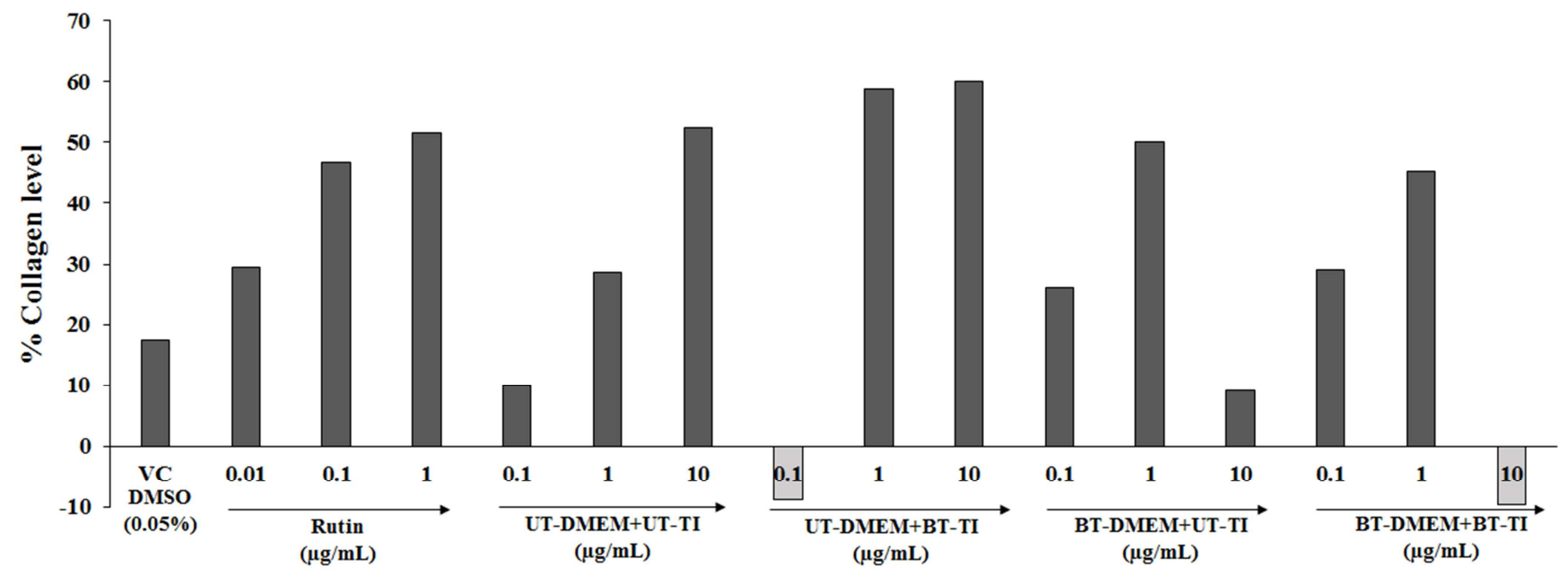

Figure 3. Estimation of collagen level in the test item on MG-63 cell line. VC: Vehicle control (DMSO-0.05\%), UT: Untreated; BT: Biofield Treated; TI: Test Item.

\subsection{Study of Bone Mineralization}

Bone mineralization leads to the formation of calcium, which provide strength and support to the bone mass. Improved level of calcium and other parameters plays an important role in the treatment of various bone diseases such as osteoporosis or other bone diseases. Bone mineralization was studied in different groups i.e. Biofield Energy Treated vit D3 and DMEM groups, which showed a significant increased level of bone mineralization on MG-63 cell line. The results are presented in term of percentage change of bone mineralization among different experimental groups in Figure 4. The positive control, rutin group showed a significant increased value of bone mineralization by $68.93 \%$, $84.60 \%$, and $134.46 \%$ at 5,10 , and $25 \mu \mathrm{g} / \mathrm{mL}$, respectively. The experimental data among test group's viz. UTDMEM+BT-TI showed a significant increased bone mineralization by $238.1 \%, 92.7 \%$, and $43.1 \%$ at $0.1,1$, and
$10 \mu \mathrm{g} / \mathrm{mL}$, respectively while BT-DMEM+UT-TI group showed a significantly increased bone mineralization by $297.6 \%, 86.2 \%$, and $66.3 \%$ at $0.1,1$, and $10 \mu \mathrm{g} / \mathrm{mL}$, respectively as compared with the untreated test item and DMEM group. However, BT-DMEM+BT-TI group showed a significant increased bone mineralization by $281 \%, 113 \%$, and $47 \%$ at $0.1,1$, and $10 \mu \mathrm{g} / \mathrm{mL}$, respectively as compared with the untreated test item and DMEM group. The experimental data suggest that bone mass would be improved due to significant change in bone mineralization, which would improve the calcium absorption in bones with reduced bone deformities and diseases [40, 41]. The results of bone mineralization showed that the Biofield Energy Healing Treatment significantly improved the rate of bone mineralization compared with the untreated groups, which can be used in various bone related disorders and recovery process.

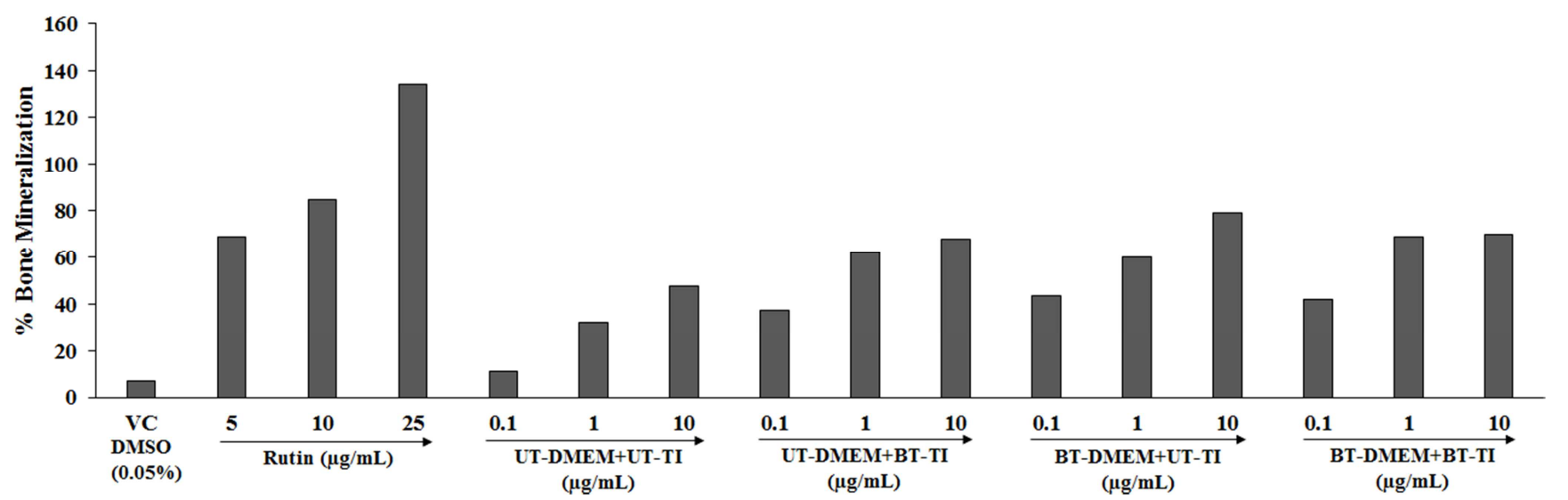

Figure 4. Estimation of bone mineralization in the test item on MG-63 cell line. VC: Vehicle control (DMSO-0.05\%), UT: Untreated; BT: Biofield Treated; TI: Test Item.

\section{Conclusions}

Cell viability test was performed using MTT assay in the MG-63 cell line, which showed that more than $88 \%$ cell viability that suggested the test samples are safe and nontoxic.
The level of ALP was increased by $273.3 \%$ at $0.1 \mu \mathrm{g} / \mathrm{mL}$ in UT-DMEM+BT-TI, while $694.1 \%$ and $36.4 \%$ at 1 and 10 $\mu \mathrm{g} / \mathrm{mL}$, respectively, in the BT-DMEM+UT-TI group as compared with the untreated test group. In addition, BTDMEM+BT-TI group showed a significant increased ALP 
level by $180.0 \%$ and $35.3 \%$ at 0.1 and $1 \mu \mathrm{g} / \mathrm{mL}$, respectively as compared with the untreated group. Collagen level was significantly increased by $105.8 \%$ and $14.5 \%$ at 1 and 10 $\mu \mathrm{g} / \mathrm{mL}$, respectively in the UT-DMEM+BT-TI, while $164.6 \%$ and $74.8 \%$ at 0.1 and $1 \mu \mathrm{g} / \mathrm{mL}$, respectively in the BTDMEM+UT-TI group. In addition, increased collagen was reported by $193.8 \%$ and $58.3 \%$ at 0.1 and $1 \mu \mathrm{g} / \mathrm{mL}$, respectively in BT-DMEM+BT-TI group as compared with the untreated test item and DMEM group. Similarly, the percent of bone mineralization was significantly increased by $238.1 \%, 92.7 \%$, and $43.1 \%$ at $0.1,1$, and $10 \mu \mathrm{g} / \mathrm{mL}$, respectively in the UT-DMEM+BT-TI group, while $297.6 \%$, $86.2 \%$, and $66.3 \%$ at $0.1,1$, and $10 \mu \mathrm{g} / \mathrm{mL}$, respectively in the BT-DMEM+UT-TI group as compared with the untreated group. In addition, BT-DMEM+BT-TI group showed a significant increase in the bone mineralization by $281 \%$, $113 \%$, and $47 \%$ at $0.1,1$, and $10 \mu \mathrm{g} / \mathrm{mL}$, respectively as compared with the untreated group. Overall, the Biofield Energy Treated (The Trivedi Effect ${ }^{\circledR}$ ) test samples were found to have a significant impact on tested bone health parameters viz. collagen, bone mineralization, and ALP, which are very vital to combat the bone disorders. Therefore, the Consciousness Energy Healing based vitamin $\mathrm{D}_{3}$ might be a suitable alternative nutritional supplement, which could be useful for the management of various bone related disorders viz. osteoporosis, Paget's disease of bone, rickets, deformed bones, osteomalacia, bone and/or joint pain, increased frequency of fractures, osteoma, hormonal imbalance, stress, aging, bone loss and fractures, and other bone diseases that are caused by poor nutrition, genetics, or problems with the rate of bone growth or rebuilding. Biofield Energy Treated Vitamin $\mathrm{D}_{3}$ can be useful as antiinflammatory, anti-aging, anti-stress, anti-arthritic, antiosteoporosis, anti-cancer, anti-apoptotic, wound healing, anti-psychotic and anti-fibrotic roles. It also influence cell-tocell communication, normal cell growth, cell differentiation, neurotransmission, cell cycling and proliferation, hormonal balance, skin health, immune and cardiovascular functions. Besides, it can also be utilized in organ transplants (for example kidney transplants, liver transplants and heart transplants), hormonal imbalance, aging, and various immune related disease conditions such as Atherosclerosis, Aplastic Anemia, Alzheimer's Disease, Asthma, Dermatomyositis, Diabetes, Dermatitis, Diverticulitis, Irritable Bowel Syndrome, Hashimoto Thyroiditis, Pernicious Anemia, Sjogren Syndrome, Multiple Sclerosis, Hepatitis, Graves' Disease, Myasthenia Gravis, Parkinson's Disease, Ulcerative Colitis, Systemic Lupus Erythematosus, stress, etc. with a safe therapeutic index to improve overall health, and quality of life.

\section{Abbreviations}

CAM: Complementary and Alternative Medicine, NCCAM: National Center for Complementary and Alternative Medicine; MG-63: Human Bone Osteosarcoma Cells, ALP: Alkaline phosphatase, DMEM: Dulbecco's
Modified Eagle's Medium, FBS: Fetal Bovine Serum, FBS: Fetal bovine serum; EDTA: Ethylene Diamine Tetra Acetic Acid, UT: Untreated, BT: Biofield Energy Treated, TI: Test Item.

\section{Acknowledgements}

Authors are grateful to Dabur Research Foundation, Trivedi Global, Inc., Trivedi Science, Trivedi Testimonials, and Trivedi Master Wellness for their support throughout the work.

\section{References}

[1] Holick MF (1996) Vitamin D and bone health. J Nutr 126: 1159S-64S.

[2] van Leeuwen JP, van Driel M, van den Bemd GJ, Pols HA (2001) Vitamin D control of osteoblast function and bone extracellular matrix mineralization. Crit Rev Eukaryot Gene Expr 11: 199-226.

[3] Bikle DD (2012) Vitamin D and bone. Curr Osteoporos Rep 10: 151-159.

[4] Lips P (2001) Vitamin D deficiency and secondary hyperparathyroidism in the elderly: consequences for bone loss and fractures and therapeutic implications. Endocrine Rev 22: 477-501.

[5] Hossein-nezhad A, Holick MF (2013) Vitamin D for health: A global perspective. Mayo Clinic proceedings Mayo Clinic 88: 720-755.

[6] Czekanska EM, Stoddart MJ, Richards RG, Hayes JS (2012) In search of an osteoblast cell model for in vitro research. Eur Cell Mater 24: 1-17.

[7] Luo XH, Liao EY (2003) Effects of estriol on the proliferation and differentiation of human osteoblastic MG-63 cells. Endocrine Res 29: 343-351.

[8] Iba K, Takada J, Yamashita T (2004) The serum level of bone-specific alkaline phosphatase activity is associated with aortic calcification in osteoporosis patients. J Bone Miner Metab 22: 594-596.

[9] Viguet-Carrin S, Garnero P, Delmas PD (2006) The role of collagen in bone strength. Osteoporos Int 17: 319-336.

[10] Bhattarai T, Bhattacharya K, Chaudhuri P, Sengupta P (2014) Correlation of common biochemical markers for bone turnover, serum calcium, and alkaline phosphatase in postmenopausal women. The Malaysian Journal of Medical Sciences : MJMS 21: 58-61.

[11] Rubik B (2002) The biofield hypothesis: Its biophysical basis and role in medicine. J Altern Complement Med 8: 703-717.

[12] Barnes PM, Bloom B, Nahin RL (2008) Complementary and alternative medicine use among adults and children: United States, 2007. Natl Health Stat Report 12: 1-23.

[13] Frass M, Strassl RP, Friehs H, Müllner M, Kundi M, Kaye $\mathrm{AD}$ (2012) Use and acceptance of complementary and alternative medicine among the general population and medical personnel: A Systematic Review. Ochsner J 12: 45-56. 
[14] Trivedi MK, Tallapragada RM (2008) A transcendental to changing metal powder characteristics. Met Powder Rep 63: $22-28,31$.

[15] Trivedi MK, Nayak G, Patil S, Tallapragada RM, Latiyal O (2015) Studies of the atomic and crystalline characteristics of ceramic oxide nano powders after bio field treatment. Ind Eng Manage 4: 161.

[16] Trivedi MK, Nayak G, Patil S, Tallapragada RM, Latiyal O, Jana S (2015) Effect of biofield energy treatment on physical and structural properties of calcium carbide and praseodymium oxide. International Journal of Materials Science and Applications 4: 390-395.

[17] Trivedi MK, Branton A, Trivedi D, Nayak G, Mondal SC, Jana S (2015) Morphological characterization, quality, yield and DNA fingerprinting of biofield energy treated alphonso mango (Mangifera indica L.). Journal of Food and Nutrition Sciences 3: 245-250.

[18] Trivedi MK, Branton A, Trivedi D, Nayak G, Mondal SC, Jana S (2015) Evaluation of biochemical marker - Glutathione and DNA fingerprinting of biofield energy treated Oryza sativa. American Journal of BioScience 3: 243-248.

[19] Trivedi MK, Branton A, Trivedi D, Nayak G, Charan S, Jana S (2015) Phenotyping and 16S rDNA analysis after biofield treatment on Citrobacter braakii: A urinary pathogen. J Clin Med Genom 3: 129.

[20] Trivedi MK, Patil S, Shettigar H, Mondal SC, Jana S (2015) Evaluation of biofield modality on viral load of Hepatitis B and $\mathrm{C}$ viruses. J Antivir Antiretrovir 7: 083-088.

[21] Trivedi MK, Patil S, Shettigar H, Mondal SC, Jana S (2015) An impact of biofield treatment: Antimycobacterial susceptibility potential using BACTEC 460/MGIT-TB System. Mycobact Dis 5: 189.

[22] Trivedi MK, Patil S, Shettigar H, Bairwa K, Jana S (2015) Phenotypic and biotypic characterization of Klebsiella oxytoca: An impact of biofield treatment. J Microb Biochem Technol 7: 203-206.

[23] Nayak G, Altekar N (2015) Effect of biofield treatment on plant growth and adaptation. J Environ Health Sci 1: 1-9.

[24] Branton A, Jana S (2017) The influence of energy of consciousness healing treatment on low bioavailable resveratrol in male Sprague Dawley rats. International Journal of Clinical and Developmental Anatomy 3: 9-15.

[25] Branton A, Jana S (2017) The use of novel and unique biofield energy healing treatment for the improvement of poorly bioavailable compound, berberine in male Sprague Dawley rats. American Journal of Clinical and Experimental Medicine 5: 138-144.

[26] Branton A, Jana S (2017) Effect of The biofield energy healing treatment on the pharmacokinetics of 25hydroxyvitamin $\mathrm{D} 3\left[25(\mathrm{OH}) \mathrm{D}_{3}\right]$ in rats after a single oral dose of vitamin D3. American Journal of Pharmacology and Phytotherapy 2: 11-18.

[27] Kinney JP, Trivedi MK, Branton A, Trivedi D, Nayak G, Mondal SC, Jana S (2017) Overall skin health potential of the biofield energy healing based herbomineral formulation using various skin parameters. American Journal of Life Sciences 5: 65-74.
[28] Singh J, Trivedi MK, Branton A, Trivedi D, Nayak G, Gangwar M, Jana S (2017) Consciousness energy healing treatment based herbomineral formulation: A safe and effective approach for skin health. American Journal of Pharmacology and Phytotherapy 2: 1-10.

[29] Trivedi MK, Branton A, Trivedi D, Nayak G, Plikerd WD, Surguy PL, Kock RJ, Piedad RB, Callas RP, Ansari SA, Barrett SL, Friedman S, Christie SL, Liu SC, Starling SE, Jones S, Allen SM, Wasmus SK, Benczik TA, Slade TC, Orban T, Vannes VL, Schlosser VM, Albino YSY, Panda P, Sethi KK, Jana S (2017) A Systematic study of the biofield energy healing treatment on physicochemical, thermal, structural, and behavioral properties of magnesium gluconate. International Journal of Bioorganic Chemistry 2: 135-145.

[30] Trivedi MK, Branton A, Trivedi D, Nayak G, Plikerd WD, Surguy PL, Kock RJ, Piedad RB, Callas RP, Ansari SA, Barrett SL, Friedman S, Christie SL, Liu SC, Starling SE, Jones S, Allen SM, Wasmus SK, Benczik TA, Slade TC, Orban T, Vannes VL, Schlosser VM, Albino YSY, Panda P, Sethi KK, Jana S (2017) Chromatographic and spectroscopic characterization of the consciousness energy healing treated Withania Somnifera (ashwagandha) root extract. European Journal of Biophysics 5: 38-47.

[31] Trivedi MK, Patil S, Shettigar H, Mondal SC, Jana S (2015) The potential impact of biofield treatment on human brain tumor cells: A time-lapse video microscopy. J Integr Oncol 4: 141.

[32] Trivedi MK, Patil S, Shettigar H, Gangwar M, Jana S (2015) In vitro evaluation of biofield treatment on cancer biomarkers involved in endometrial and prostate cancer cell lines. J Cancer Sci Ther 7: 253-257.

[33] Czekanska EM, Stoddart MJ, Richards RG, Hayes JS (2012) In search of an osteoblast cell model for in vitro research. Eur Cells Mater 24: 1-17.

[34] Biological evaluation of medical devices - Part 5: Tests for in vitro cytotoxicity (ISO 10993-5:2009), I.S.EN ISO, 109935:20093.

[35] Sharma U, Pal D, Prasad R (2014) Alkaline phosphatase: An overview. Indian J Clin Biochem 29: 269-278.

[36] Orimo $H$ (2010) The mechanism of mineralization and the role of alkaline phosphatase in health and disease. J Nippon Med Sch 77: 4-12.

[37] Golub EE, Boesze-Battaglia K (2007) The role of alkaline phosphatase in mineralization. Curr Opin Orthop 18: 444-448.

[38] Black C, Clar C, Henderson R, MacEachern C, McNamee P, Quayyum Z, Royle P, Thomas S (2009) The clinical effectiveness of glucosamine and chondroitin supplements in slowing or arresting progression of osteoarthritis of the knee: A systematic review and economic evaluation. Health Technol Assess 13: 1-148.

[39] Lodish H, Berk A, Zipursky SL, et al. Molecular Cell Biology. 4th edition. New York: W. H. Freeman; 2000. Section 22.3, Collagen: The fibrous proteins of the matrix.

[40] Seeman E (2009) Bone modeling and remodeling. Crit Rev Eukaryot Gene Expr 19: 219-233.

[41] Laird E, Ward M, McSorley E, Strain JJ, Wallace J (2010) Vitamin D and bone health; Potential mechanisms. Nutrients 2: 693-724. 